現場改善へのバーチャルファクトリーシミュレーションと

その有効性について

\author{
○舟田尚康、三上行生、渋谷正弘 (北海道工業大学) \\ 飯田憲一、烟沢賢一 (道工試)、神代雅晴（産業医科大学）
}

\title{
An examination of effectiveness of Virtual Factory Simulation for work improvement
}

Naoyasu Funada、Koki Mikami、Shibuya Masahiro (Hokkaido Institute of Tech.)

Kenichi Iida、 Kenichi Hatazawa (Hokkaido Industrial Research Institute) Masaharu Kumasiro (UOEH,Japan)

\section{1. はじめに}

今日、生産システム効率化に対し VR(Virtual Reality) 技術を応用したシミュレーションが注 目を集めている。現場作業効率化への VF(Virtual Factory)シミュレーションの有効性の 検討は、企業においては事前に改善投資効果の 評価を可能とすることから、関心事となってい

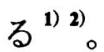

本研究では、化精品工場を対象として新規事 業への人員配属のために生ずる少人化対策ライ ンを例にとり、現場改善へのVFシミュレー ションの有効性について検討した。

\section{2. 方法}

1)本研究で使用したVFシミュレータはQUEST (Queuing Event Simulation Tool:米国 Deneb Robotics 社開発)である。

2)対象ラインの害調査と VTRの分析結果から、 解析に必要なパラメータを抽出し、それらパラ メータ、すなわち各工程の作業時間・作業内容、 作業者の運搬時間、袋詰め機から出力される製 品の発生間隔、仕掛り 量、製品の移動経路、な らびに設備サイズを求めた。次いで、下記の手 順に沿って少人化のためのシミュレーションを 実行した。

3)モデル作成とシミュレーション手順

(1)対象となる工場レイアウトを実寸で作成 (2)レアウト上に必要な設備類を配直 (3)ワクの移動経路の設定

(4)設備・作業者に必要なパラメータ值の入力
(5)ミュレーションの実施と評価

(6)手順(2) 一戻り 実行可能な最適案に近づける

\section{3. 結果と考察}

\section{1)現状レイアウト及び作粪内容}

対象ラインの各工程の作業内容、レイアウト 及び作業人員を Fig.1 に示す。

第 1 工程では、袋詰め機より出される小袋製 品の箱入れ作業を 2 名で行い、第 2 工程は取扱 説明書の挿入と箱とじ作業及び仕掛品の移動、 第3工程は製品流し 作業、第4工程は検査作業、 第5工程はロットシール貼り作業、第 6 工程は 相包作業となっており、それぞれ1名で行って いる。

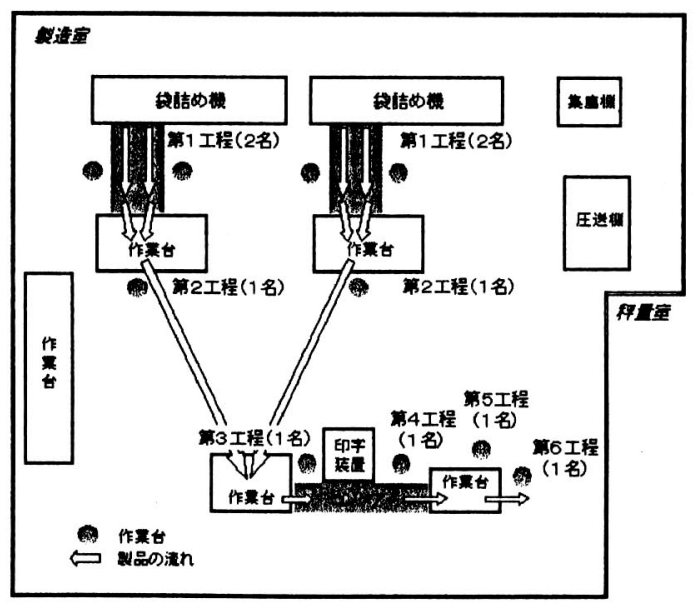

Fig.1 対象ラインレイアウト及び作羓人員 


\section{2)現状及び改善モデル茟築}

手順に従い、シミュレータの仮想空間上に現 状モデル及び、分析結果から 2つの改善策を立 案し、その改善モデルを構筑した。

本研究では、現状ラインを忠実にシミュレー タ上に再現し、シミュレーションを実行させる ため、既存のパラメータにはない条件設定に関 しては、SCL(Simulation Control Language)を用 い新たなプログラムを作成した。

プログラム作成を必要としたパラメータは、 (1)作業者の運搬時間、(2)作業者の手持ち仕掛り 量である。

\section{3)シミュレーションの实施}

シミュレーションは、“袋詰め機 2 台・作業者 数 10名ならびに袋詰め機 3 台・作業者数 13 名で 行っている現状作業”之、“袋詰め機 2 台で 各々、作業の分割·統合を行い、作業者数を 8 名 とした場合の改善案 1”と、“袋詰め機を 3 台で 作業者数を 11 名で実施した場合の改善案 2”の 計 4モデルのシミュレーションを実行した。

Fig.2、3はシミュレーション時における改善 案1·2の実行画面である。

\section{4）現場改䓺へのVFシミュレーションの有効性 について}

改善案に対するシミュレーションでは、現行、 機械 2 台の場合 10 名体制から8名体制への移行、 機械3台の場合は現行 13 名体制から 11 名での移 行の可能性とかつ生産性の向上をもたらす改善効 果が明らかとなった。

しかし、れれは通常シミュレーションによっ て得られるメリットとして当然のごとく述べらる 事項である。

本研究を通してのVFシミュレーションの1番 のメリットは、シミュレータ上の改善案を実行に 移す場合には、現場において多くの細かな改善を 必要とすることになりこれを職場全員に視覚的に 理解させ、実行させる基盤作りに何よりも貢献で きる点である。

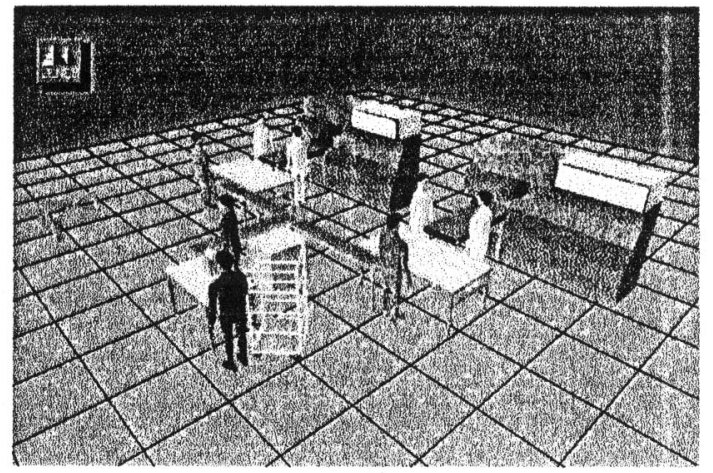

Fig.2 改善萫 1 の实行画面

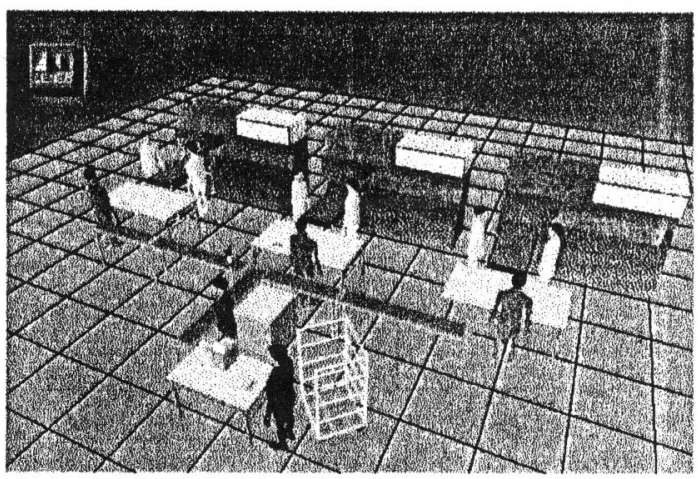

Fig.3 改善莱 2 の実行画面

\section{4. まとめ}

VFシミュレーションと現場改善活動の融合こそ が真のVFシミュレーションの有効性に結びつく ものと考えられる。

\section{参考文献}

1)仲町英治: ヴァーチャルファクトリー 未来 工場一の挑戦 工業調査会

2)野口恒: バーチャルファクトリー 超収益 企業への挑戦 日刊工業新聞社 